\title{
Biases in determining the diet of jumbo squid Dosidicus gigas (D' Orbigny 1835) (Cephalopoda: Ommastrephidae) off southern-central Chile $\left(34^{\circ} \mathrm{S}-40^{\circ} \mathrm{S}\right)$
}

\author{
Christian M. Ibáñez · Hugo Arancibia • \\ Luis A. Cubillos
}

Received: 15 January 2008/Revised: 24 May 2008/Accepted: 5 June 2008/Published online: 24 June 2008

(C) Springer-Verlag and AWI 2008

\begin{abstract}
The diet of jumbo squid (Dosidicus gigas) off southern-central Chile is described to examine potential biases in the determination of their main prey. Specimens were collected from catches using different fishing gear (jigging, trawl and purse-seine), from July 2003 to January 2004, and from December 2005 to October 2006. The stomach contents were analyzed in terms of frequency of occurrence, number, and weight of prey items and the diet composition was analyzed using Detrended Correspondence Analysis. In the industrial purse-seine fleet for jack mackerel (Trachurus murphyi), the dominant prey of $D$. gigas was $T$. murphyi. In the industrial mid-trawl fishery for Patagonian grenadier (Macruronus magellanicus), the dominant species in the diet of D. gigas was M. magellanicus. Similarly, Chilean hake (Merluccius gayi) was the main prey in the diet of D. gigas obtained in the industrial trawl fishery for Chilean hake; and, in both artisanal fisheries (purse-seine for small pelagics and jigging), small pelagic fish and D. gigas were the main prey in the stomach contents of D. gigas. Cannibalism in D. gigas varied between different fleets and probably is related to stress behavior during fishing. The Detrended Correspondence Analysis ordination showed that the main prey in the diet
\end{abstract}

Communicated by M. Thiel.

C. M. Ibáñez $(\square)$

Departamento de Ciencias Ecológicas, Facultad de Ciencias, Instituto de Ecología y Biodiversidad, Universidad de Chile, Casilla 653, Santiago, Chile

e-mail: christianibez@yahoo.com

H. Arancibia - L. A. Cubillos

Departamento de Oceanografía, Facultad de Ciencias Naturales y Oceanográficas, Universidad de Concepción, Casilla 160-C,

Concepcion, Chile of D. gigas is associated with the target species of the respective fishery. Consequently, biases are associated with fishing gear, leading to an overestimate in the occurrence of the target species in the diet. We recommend analyzing samples from jigging taken at the same time and place where the trawl and purse-seine fleets are operating to avoid this problem, and the application of new tools like stable isotope, heavy metal, and fatty acid signature analyses.

Keywords Dosidicus gigas . Predation and bias . Fisheries · Chile

\section{Introduction}

Cephalopods play an important role in the trophic structure of marine ecosystems worldwide as they are voracious predators with high metabolic rates (Amaratunga 1983; Rodhouse and Nigmatullin 1996). Populations are subject to dramatic fluctuations and their impact on prey populations is equally variable (Rodhouse and Nigmatullin 1996).

The jumbo squid Dosidicus gigas (D`Orbigny 1835) is one of the largest, most abundant and active predators in the Eastern Pacific Ocean (Nigmatullin et al. 2001). Off Chile, D. gigas exhibits sporadic and short-term pulses in abundance, which can be deduced from catch records that have been available since 1957 (Rocha and Vega 2003). Recently (since 2001), a new period of high abundance of D. gigas has occurred off southern-central Chile $\left(34^{\circ} \mathrm{S}-40^{\circ} \mathrm{S}\right)$ (Ibáñez and Cubillos 2007; Zúñiga et al. 2008). Because the incidence of D. gigas as bycatch in traditional fisheries has become important, fishery managers are concerned about the potential predatory impact of jumbo squid on fishing stocks, such as jack mackerel 
(Trachrus murphyi), Chilean hake (Merluccius gayi), small pelagic fishes (Engraulis ringens and Strangomera bentincki), and Patagonian grenadier (Macruronus magellanicus). Historically, D. gigas has been caught incidentally only by artisanal boats when the abundance of this species has been high (Fernández and Vásquez 1995). Recently, the incidence of D. gigas as bycatch (percentage in weight) by industrial vessels has ranged from 0.3 to $2 \%$ (Cubillos et al. 2004). Nevertheless, the trophic ecological impact on fish populations is unknown.

The diet of D. gigas has been studied in various parts of its distribution (see reviews in Clarke and Paliza 2000 and Nigmatullin et al. 2001). According to Nigmatullin et al. (2001), the most common prey items are copepods, hyperiid amphipods, euphausiids, pelagic shrimps and red crabs, heteropod mollusks, squids, pelagic octopods and various fishes. In northern-central Chile $\left(29^{\circ} \mathrm{S}-30^{\circ} \mathrm{S}\right)$, Fernández and Vásquez (1995) and Chong et al. (2005) found in the stomach contents of D. gigas the following prey: jack mackerel (Trachurus murphyi), Chilean hake (Merluccius gayi), small pelagics (Engraulis ringens, Strangomera bentincki and Sardinops sagax), squids and crustaceans. From southern-central Chile, Wilhelm (1930, 1954) reported the following prey species in the stomach contents of D. gigas that had stranded in Talcahuano $\left(36.7^{\circ} \mathrm{S}\right)$ : Chilean hake (M. gayi), sardine (S. sagax), lings (Genypterus spp.), benthic crustaceans and conspecifics. Recently, Ulloa et al. (2006) described the diet of D. gigas from southern-central Chile $\left(36^{\circ} \mathrm{S}-38^{\circ} \mathrm{S}\right)$ and found that the frequency of prey did not vary in relation to sex or ontogeny. For the northern hemisphere, Markaida and Sosa-Nishizaki (2003) analyzed the stomach contents of 533 large-sized individuals of $D$. gigas from the Gulf of California between 1995 and 1997, and identified mainly myctophids, pelagic red squat lobsters (Pleuroncodes planipes), and micronektonic squid. Moreover, they found greater spatial and temporal variation in the main prey than between ontogenetic or sexual stages. The same general pattern was found in medium size individuals of $D$. gigas caught in the Gulf of California after the El Niño event of 1997-1998 (Markaida 2006).

Studies on food habits in general, and those for cephalopods in particular, suffer from a broad array of potential shortcomings and biases (Santos et al. 2001; Field et al. 2007). Voracious feeding behavior, even when captured, means that cephalopods from net tows may feed after capture and consequently stomach contents may not reflect their natural diet (Rodhouse and Nigmatullin 1996), because during fishing with purse-seine and trawls squids continue to feed on target species and conspecifics (Breiby and Jobling 1985; Rodhouse and Nigmatullin 1996; Nigmatullin 2005; Olson et al. 2006; Field et al. 2007). For example, there is no evidence that $D$. gigas preys on tuna when not confined in a net (Olson et al. 2006). Thus, it is difficult to evaluate whether the stomach contents of individuals of $D$. gigas caught in other nets reflect any natural feeding at all. Instead, stomach contents of D. gigas may depend on the target species, fishing gear and fishing grounds of the respective fisheries. For example, Ulloa et al. (2006) found up to $78 \%$ of $M$. gayi in the diet of $D$. gigas in samples obtained from the catch of the industrial trawl fleet targeting Chilean hake. It is likely that samples of D. gigas stomachs caught with jigging avoid this heavy bias. Although jigging does not prevent the occurrence of artificial cannibalism (Markaida and Sosa-Nishizaki 2003), it largely avoids interaction with other commercial species.

While there is relatively good information about the diet of D. gigas in the central E Pacific, it is not well known for the more austral range of its distribution, i.e., off the Chilean coast. In this paper, we present results on the diet and biases in determination of the main prey of D. gigas with stomach samplings obtained from different fisheries and with different fishing gear off southerncentral Chile.

\section{Materials and methods}

From July 2003 to January 2004, 70 stomachs of D. gigas were obtained from the bycatch of the jack mackerel (Trachurus murphyi) industrial purse-seine fleet (IPSF) in oceanic waters, operating at depths between 10 and $70 \mathrm{~m}$. 110 stomachs were sampled from the industrial mid-water trawl fleet fishing (IMTF) for Patagonian grenadier ( $\mathrm{Ma}$ cruronus magellanicus) during the period July to December 2003. 210 stomachs were obtained from the industrial trawl fleet (ITRF) fishing for Chilean hake (Merluccius gayi) between April and October 2006. Both these industrial fleets operate on the continental shelf primarily close to the shelf-slope at depths from 120 to $405 \mathrm{~m} .108$ stomachs were sampled from the artisanal purse-seine fleet (APSF) between December 2005 and February 2006 where sardine and anchovy (Strangomera bentincki and Engraulis ringens) are the target species. Finally, 83 stomachs were obtained from an artisanal jigging fleet (AJGF) off southern-central Chile, between January and February 2006, where D. gigas is the target species. Both artisanal fleets operate in the neritic zone (approximately 5 nautical milles from the coast) fishing from the surface to a depth of $20 \mathrm{~m}$. Fig. 1 shows the spatial distribution of the different fleets on the continental shelf in southern-central Chile.

The stomachs of $D$. gigas were maintained in ice in the field and maintained frozen in laboratory until analysis. For all individuals of D. gigas, the dorsal mantle length was measured $(\mathrm{ML}, \mathrm{cm})$ and total body weight was recorded 

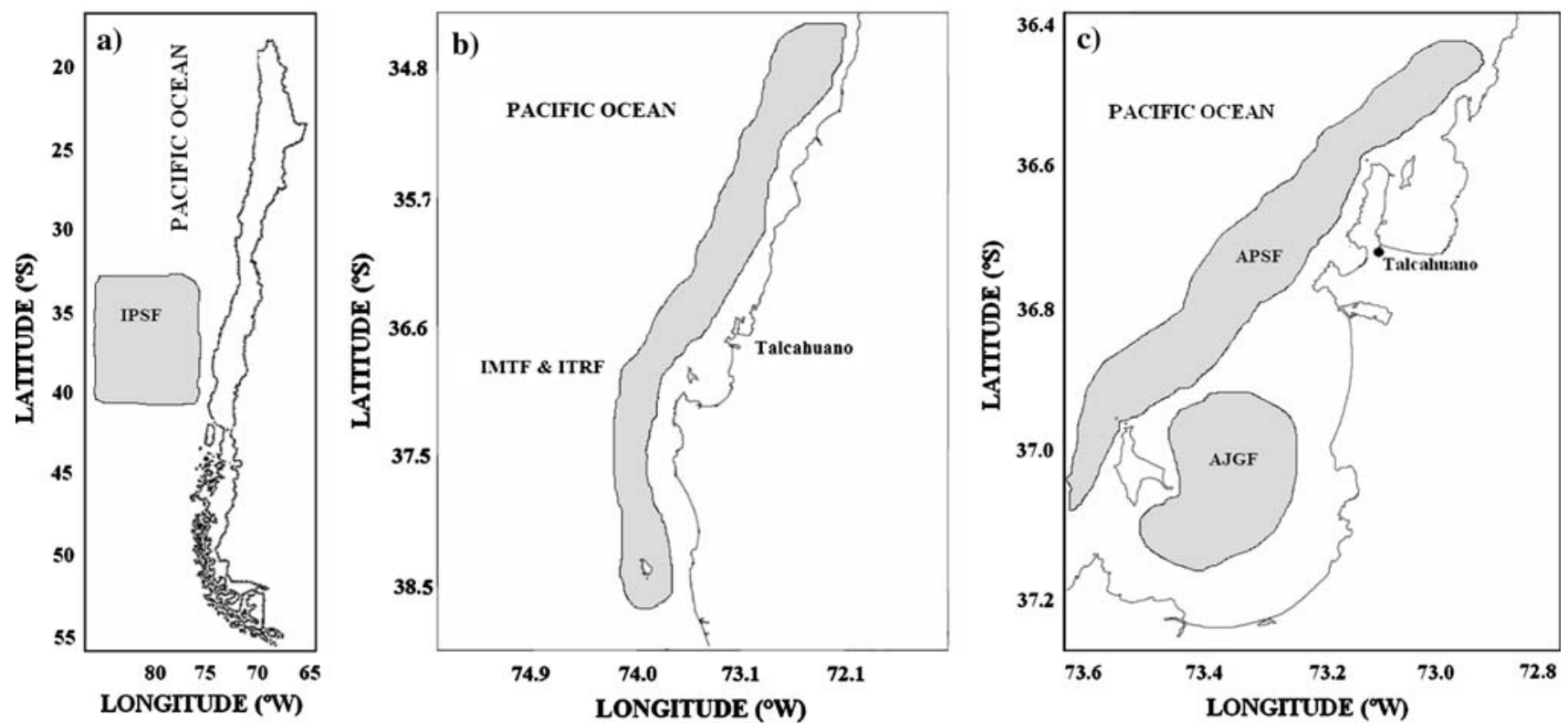

Fig. 1 Map showing the zone of collection of squids. a Oceanic zone, b Continental shelf zone, c Neritic zone. Fisheries nomenclature: IMTF Industrial Mid-Water Trawl Fleet; ITRF Industrial Trawl

(BW, kg). We used a length-weight relationship (Ibáñez and Cubillos 2007) to estimate body weight when it was not available, particularly for specimens damaged during the fishing process. The differences in mantle length, weight and stomach contents weight of squids captured with different fishing gear were tested by means of ANOVA (Zar 1984).

The stomach content of each sample was weighed $(\mathrm{g})$ and prey items were identified using specialized literature (Retamal 1981; Nesis 1987; Falabella et al. 1995) and reference collections. To describe the diet in each fleet, the frequency of occurrence $(\% \mathrm{FO})$, numeric $(\% \mathrm{~N})$, and gravimetric (\%W) methods were used (Hyslop 1980).

Diet composition was described using an ordination carried out on the frequency of occurrence matrix of preypredators, with a Detrended Correspondence Analysis (DCA; Jongman et al. 1995), following Muñoz et al. (2002) and Pardo-Gandarillas et al. (2004). This method allows
Fleet; APSF Artisanal Purse-Seine Fleet; AJGF Artisanal Jigging Fleet; IPSF Industrial Purse-Seine Fleet

the simultaneous display of samples and species in a reduced space (Jongman et al. 1995).

\section{Results}

The mantle length and body weight of D. gigas were significantly different between samples (one-way ANOVA, $F_{4,638}=115.55, P<0.001 ; F_{4,638}=37.12, P<0.001$, respectively) (Table 1). The number of empty stomachs was very low (Table 1) and the weight of stomach contents was significantly different between samples (one-way ANOVA, $F_{4,638}=5.286, P<0.001$ ) (Fig. 2).

In the industrial purse-seine fishery the main prey species in the stomachs of D. gigas was T. murphyi (Table 2). The most frequent prey species in the diet of D. gigas sampled from catches of the industrial mid-water trawl fishery for Patagonian grenadier (Macruronus magellanicus) was

Table 1 Number of stomachs of D. gigas obtained by fishery, average \pm SD of length (mantle length, $\mathrm{cm}$ ) and body weight (kg)

\begin{tabular}{llllll}
\hline & IPSF & IMTF & ITRF & APSF & AJGF \\
\hline Stomachs & $70(6)$ & $110(11)$ & $229(19)$ & $131(23)$ & $103(20)$ \\
Length $(\mathrm{ML}, \mathrm{cm})$ & $51.4 \pm 12.9(30-84)$ & $62.4 \pm 12.7(31-82)$ & $77.7 \pm 8.6(39-85)$ & $68.4 \pm 6.0(50-86)$ & $71.8 \pm 5.7(61-89)$ \\
Weight $(\mathrm{kg})$ & $5.6 \pm 4.2(3.2-17.6)$ & $9.4 \pm 5.3(4.3-25.6)$ & $21.6 \pm 17.7(3.8-22)$ & $11.3 \pm 3.3(5.5-21.5)$ & $13.9 \pm 3.5(8.0-23)$ \\
\hline
\end{tabular}

The number of empty stomachs and the range of length and weight are showed in brackets

Fisheries nomenclature: IMTF Industrial Mid-Water Trawl Fleet, ITRF Industrial Trawl Fleet, APSF Artisanal Purse-Seine Fleet, AJGF Artisanal Jigging Fleet, IPSF Industrial Purse-Seine Fleet 


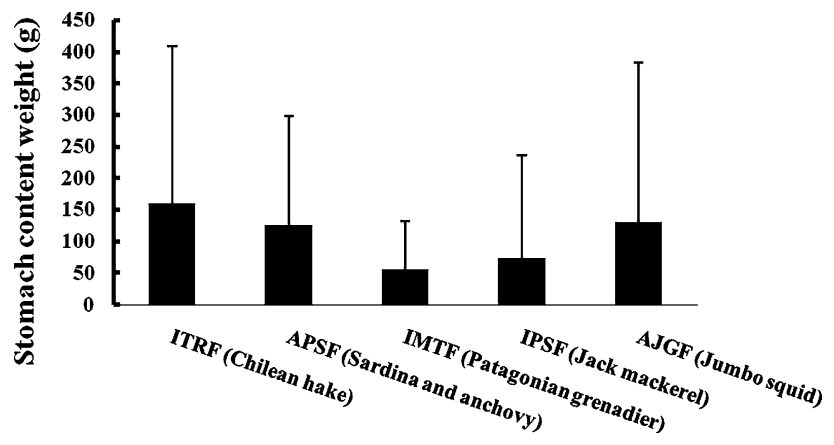

Fig. 2 Stomach contents weight average of squids captures with different fishing gear. The bars represent standard deviance

Table 2 Frequency of occurrence $(\% \mathrm{~F})$, number $(\% \mathrm{~N})$, and weight $(\% \mathrm{~W})$ in prey items contributing to the diet of D. gigas from the industrial purse-seine fishery off southern-central Chile $(n=64$ stomachs)

\begin{tabular}{lrrr}
\hline Prey & F\% & N\% & W\% \\
\hline Teleostei & & & \\
Trachurus murphyi ${ }^{\mathrm{a}}$ & 59.4 & 53.3 & 62.4 \\
Scomber japonicus & 1.6 & 1.0 & 6.6 \\
Electrona sp. & 7.8 & 7.6 & 3.0 \\
Lampadena sp. & 4.7 & 3.8 & 2.7 \\
Hygophum sp. & 14.1 & 10.5 & 4.1 \\
Diaphus sp. & 3.1 & 1.9 & 0.5 \\
Myctophidae indet. & 4.7 & 2.9 & 0.9 \\
Cephalopoda & & & \\
Dosidicus gigas & 7.8 & 4.8 & 18.3 \\
Gonatus antarcticus & 1.6 & 1.0 & 0.3 \\
Ommastrephidae indet. & 3.1 & 1.9 & 0.1 \\
Crustacea & & & \\
Euphausiacea & 10.9 & 6.7 & 0.7 \\
Crustacea indet. & 7.8 & 4.8 & 0.4 \\
Total & & 105 & $2,801.9$ \\
\hline
\end{tabular}

${ }^{a}$ Target species in this fishery

M. magellanicus (Table 3). In the industrial trawl fishery for Chilean hake (Merluccius gayi) the main prey item of D. gigas was M. gayi (Table 4). In the artisanal purse-seine fleet for small pelagics the most frequent prey were D. gigas, Strangomera bentincki and euphausiids (Table 5), while in the artisanal jigging fishery for $D$. gigas, the most frequent prey were $S$. bentincki, D. gigas, M. gayi and Myctophidae (Table 6). Thus, the diet of D. gigas is clearly different between fisheries, as the stomachs sampled showed a variable trophic spectrum.

Eigenvalues of DCA ordination of 25 prey taxa and the 5 kinds of fleet were $\lambda_{1}=0.68, \lambda_{2}=0.42, \lambda_{3}=0.26$, $\lambda_{4}=0.10$ from the first to the fourth axes (compositional gradients), respectively. The first two compositional gradients accounted for $75 \%$ of the total inertia, a measurement
Table 3 Frequency of occurrence $(\% \mathrm{~F})$, number $(\% \mathrm{~N})$, and weight $(\% \mathrm{~W})$ in prey items contributing to the diet of D. gigas from the industrial mid-trawl fishery off southern-central Chile $(n=99$ stomachs)

\begin{tabular}{|c|c|c|c|}
\hline Prey & $\mathrm{F} \%$ & $\mathrm{~N} \%$ & $\mathrm{~W} \%$ \\
\hline \multicolumn{4}{|l|}{ Teleostei } \\
\hline Merluccius gayi & 7.1 & 4.2 & 8.6 \\
\hline Macruronus magellanicus ${ }^{\mathrm{a}}$ & 41.4 & 20.2 & 39.0 \\
\hline Caelorhinchus caelorhinchus & 5.1 & 1.9 & 2.3 \\
\hline Epigonus crassicaudus & 5.1 & 2.3 & 7.2 \\
\hline Hygophum sp. & 16.2 & 15.2 & 7.5 \\
\hline Diaphus sp. & 14.1 & 22.4 & 4.1 \\
\hline Electrona sp. & 6.1 & 2.3 & 2.7 \\
\hline Lampadena sp. & 5.1 & 2.7 & 0.7 \\
\hline Myctophidae indet. & 9.1 & 4.9 & 7.5 \\
\hline Engraulis ringens & 1.0 & 0.4 & 0.1 \\
\hline \multicolumn{4}{|l|}{ Cephalopoda } \\
\hline Dosidicus gigas & 34.3 & 12.9 & 17.9 \\
\hline Gonatus antarcticus & 4.0 & 3.0 & 0.9 \\
\hline Todarodes filippovae & 3.0 & 1.1 & 0.2 \\
\hline Moroteuthis sp. & 1.0 & 1.5 & 0.002 \\
\hline Ommastrephidae indet. & 1.0 & 0.4 & 0.1 \\
\hline Cranchiidae indet. & 2.0 & 0.8 & 0.1 \\
\hline Paralarvae Octopodidae & 1.0 & 0.4 & 0.002 \\
\hline \multicolumn{4}{|l|}{ Crustacea } \\
\hline Acanthephyra sp. & 2.0 & 0.8 & 0.01 \\
\hline Galatheidae indet. & 2.0 & 0.8 & 0.6 \\
\hline Euphausiacea & 5.1 & 1.9 & 0.6 \\
\hline Total & & 263 & $5,536.1$ \\
\hline
\end{tabular}

${ }^{a}$ Target species in this fishery

of the association between predator and prey. For this reason, the information was sufficient to reveal a significant association $\left(\chi_{104}^{2}=1091.6, P<0.001\right)$ between prey and fisheries, indicating that the stomach contents of $D$. gigas depend on the method of capture of squids. Moreover, some patterns were identified from the dimensional graphs, because some prey were positioned at the extremes of the first compositional gradient, but other prey were positioned at the extremes of the second compositional gradient associated with different fisheries (Fig. 3). APSF and AJGF were associated with $E$. ringens, $S$. bentincki, $N$. crockeri and $E$. analoga; IMTF with $M$. magellanicus, C. caelorhinchus and Diaphus sp.; ITRF with $M$. gayi and Euphausiacea; and IPSF was associated with T. murphyi, S. japonicus and Ommastrephidae (Fig. 3).

\section{Discussion}

The stomach contents of individuals of D. gigas varied markedly with the origin of the stomach samples indicating 
Table 4 Frequency of occurrence $(\% \mathrm{~F})$, number $(\% \mathrm{~N})$, and weight $(\% \mathrm{~W})$ of the prey items contributing to the diet of D. gigas from the industrial trawl fishery off southern-central Chile ( $n=210$ stomachs)

\begin{tabular}{lrrr}
\hline Prey & $\% \mathrm{~F}$ & $\% \mathrm{~N}$ & $\% \mathrm{~W}$ \\
\hline Teleostei & & & \\
Merluccius gayi ${ }^{\mathrm{a}}$ & 100 & 57.1 & 92.2 \\
Diaphus sp. & 2.4 & 28.6 & 1.6 \\
Hygophum sp. & 0.5 & 1.4 & 2.3 \\
Mollusca & & & \\
Dosidicus gigas & 3.3 & 10.0 & 3.7 \\
Crustacea & & & \\
Emerita analoga & 0.5 & 1.4 & 0.05 \\
Decapoda & 0.5 & 1.4 & 0.001 \\
Total & & 70 & $2,482.5$ \\
\hline
\end{tabular}

a Target species in this fishery

Table 5 Frequency of occurrence $(\% \mathrm{~F})$, number $(\% \mathrm{~N})$, and weight $(\% \mathrm{~W})$ of the prey items contributing to the diet of D. gigas from the artisanal purse-seine fishery off southern-central Chile $(n=108$ stomachs)

\begin{tabular}{lrcr}
\hline Prey & $\% \mathrm{~F}$ & $\% \mathrm{~N}$ & $\% \mathrm{~W}$ \\
\hline Teleostei & & & \\
Engraulis ringens $^{\mathrm{a}}$ & 10.2 & 0.1 & 0.7 \\
Strangomera bentincki $^{\mathrm{a}}$ & 31.5 & 4.3 & 25.0 \\
Normanichthys crockeri $^{\mathrm{N}}$ & 11.1 & 0.5 & 1.2 \\
Merluccius gayi & 4.6 & 0.04 & 0.9 \\
Macruronus magellanicus & 0.9 & 0.02 & 0.1 \\
Mollusca & & & \\
Dosidicus gigas & 63.9 & 0.3 & 33.7 \\
Nassarius gayi & 0.9 & 0.004 & 0.002 \\
Crustacea & & & 38.4 \\
Euphausiacea & 18.5 & 94.8 & $7,131.1$ \\
Total & & 23,975 & \\
\hline
\end{tabular}

${ }^{a}$ Target species in this fishery

that the squids are able to consume a wide spectrum of prey (6-20 species) in the waters off southern-central Chile. This confirms the commonly accepted idea that cephalopods are opportunistic predators (Amaratunga 1983; Rodhouse and Nigmatullin 1996). However, the wide trophic spectrum of $D$. gigas only demonstrates that it has a generalized diet. Opportunistic hunting behavior must be statistically proven by correlating the stomach contents with the relative abundance of prey in their habitat (Jaksic and Marone 2007). Previous studies have shown that $D$. gigas are opportunistic predators (Nigmatullin et al. 2001; Markaida and Sosa-Nishizaki 2003; Markaida 2006; Ulloa et al. 2006; Field et al. 2007), however, there is currently insufficient evidence and this should be considered a hypothesis that has yet to be confirmed.
Table 6 Frequency of occurrence $(\% \mathrm{~F})$, number $(\% \mathrm{~N})$, and weight (\%W) of the prey items contributing to the diet of D. gigas from the artisanal jigging fishery off southern-central Chile ( $n=83$ stomachs)

\begin{tabular}{|c|c|c|c|}
\hline Prey & $\% \mathrm{~F}$ & $\% \mathrm{~N}$ & $\% \mathrm{~W}$ \\
\hline \multicolumn{4}{|l|}{ Teleostei } \\
\hline Engraulis ringens & 9.6 & 0.3 & 0.2 \\
\hline Strangomera bentincki & 59.0 & 93.4 & 71.8 \\
\hline Trachurus murphyi & 1.2 & 0.03 & 0.01 \\
\hline Normanichthys crockeri & 7.2 & 4.2 & 0.6 \\
\hline Merluccius gayi & 14.5 & 0.4 & 15.0 \\
\hline Macruronus magellanicus & 3.6 & 0.1 & 5.7 \\
\hline Caelorhinchus sp. & 1.2 & 0.03 & 0.04 \\
\hline Hygophum sp. & 3.6 & 0.1 & 0.2 \\
\hline Myctophidae indet. & 12.0 & 0.6 & 0.7 \\
\hline \multicolumn{4}{|l|}{ Mollusca } \\
\hline Dosidicus gigas ${ }^{\mathrm{a}}$ & 28.9 & 0.7 & 5.8 \\
\hline Nassarius gayi & 1.2 & 0.03 & 0.0004 \\
\hline \multicolumn{4}{|l|}{ Crustacea } \\
\hline Emerita analoga & 1.2 & 0.03 & 0.003 \\
\hline Total & & 3,260 & $10,710.9$ \\
\hline
\end{tabular}

a Target species

Differences in length and weight of squid captured with different fishing gear were associated with spatial and temporal variations in jumbo squid body size in Chilean waters (Chong et al. 2005; Ibáñez and Cubillos 2007). The weight of stomach contents varied between samples, partly as a consequence of the travel times involved between the fishing grounds and the laboratory. Stomachs obtained from the industrial fleets (IPSF, IMTF and ITRF) were maintained in ice for between 24 and $48 \mathrm{~h}$ prior to freezing in the laboratory, while for both artisanal fleets (APSF and AJGF) the times were 2 to $3 \mathrm{~h}$.

Traditional methods of dietary analysis include counts, frequency of occurrence, and volume or weight of individual prey items (Hyslop 1980). Each of these measures produces a different biased insight into the feeding habits of a predator. Weights of prey are underestimates depending on the degree of digestion. For this reason, the frequency of occurrence and number of prey are better predictors of the predator diet than weight and Relative Importance Index (RII, Pinkas et al. 1971), because these incorporate strong biases (Ibáñez et al. 2004). However, the number of prey is more dependent on the hard structures found in stomachs such as otoliths and beaks. Bias may also result when heads are not consumed in larger prey (Field et al. 2007), and the presence and number of this structure lead to underestimates. On the other hand, accumulation of beaks in the stomach overestimates the number of prey (Vaske-Júnior and Rincón-Filho 1998) while otoliths do not accumulate in the stomachs of marine 


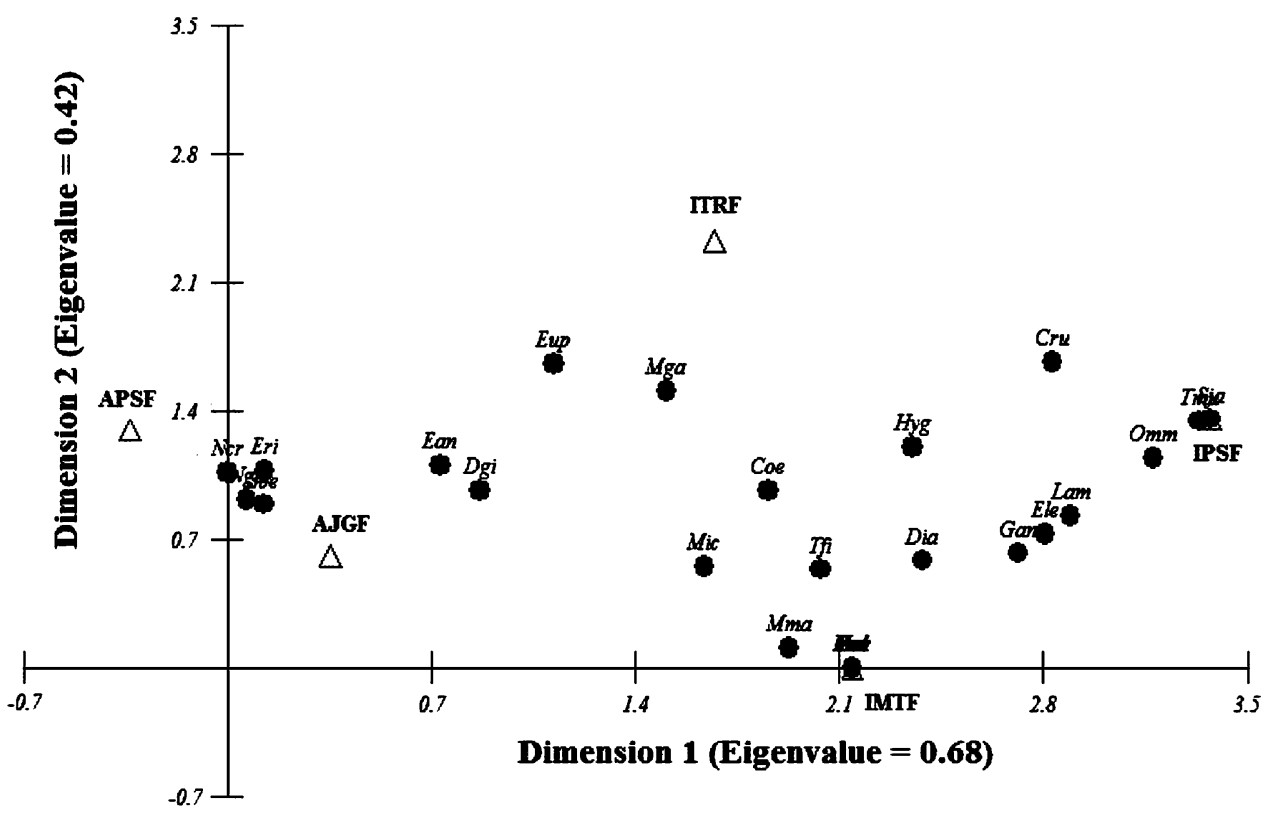

Fig. 3 Bi-plot ordination of Detrended Correspondence Analysis showing the position of fisheries and prey in a reduced space. Fisheries nomenclature: IMTF Industrial Mid-Water Trawl Fleet; ITRF Industrial Trawl Fleet; APSF Artisanal Purse-Seine Fleet; $A J G F$ Artisanal Jigging Fleet; IPSF Industrial Purse-Seine Fleet. Nomenclature prey: Act Acanthephyra sp., Coe Coelorhynchus sp., Cra Cranchiidae, Crus Crustacea, Dgi Dosidicus gigas, Dia Diaphus sp.,

piscivores, and any otoliths found only represent the remains of the most recent feeding bout (Jobling and Breiby 1986). In the case of cephalopods, we recommend the use of a presence-absence matrix of prey-predators to describe the diet by calculating the frequency of occurrence and composition gradients by means of multivariate ordination techniques like DCA or Non-metric Multidimensional Scaling (NMDS). Another bias in describing the diet of predators is insufficient sample size. Cumulative prey curves, trophic diversity curves and rarefaction curves help to determine whether a sufficient number of samples have been collected to precisely describe the diet of a particular predator (Markaida and Sosa-Nishizaki 1998; Castillo et al. 2007).

Results of this study show that stomach contents of $D$. gigas are fishing gear-dependent, because when $D$. gigas fed within the net, the recently consumed target species were less well digested (bite-sized pieces) than the other prey in the stomach (C. Ibáñez personal observation). Thus, the method of capture dictates the results that will emerge, as during fishing operations individuals of $D$. gigas feed on the target species (see also Nigmatullin 2005; Olson et al. 2006; Field et al. 2007). In this sense, we suggest that the stomach contents of D. gigas reported by Ulloa et al. (2006) seriously overestimated the occurrence of Chilean hake (M. gayi), because they analyzed samples obtained
Ean Emerita analoga, Ecr Epigonus crassicaudus, Ele Electrona sp., Eri Engraulis ringens, Eup Euphausiacea, Gan Gonatus antacticus, Hyg Hygophum sp., Lam Lampadena sp., Mga Merluccius gayi, Mic Myctophidae, Mma= Macruronus magellanicus, Mor Moroteuthis sp., Ncr Normanichthys crockery, Nga Nassarius gayi, Omm Ommastrephidae, Poc Paralarvae Octopodidae, Sbe Strangomera bentincki, Sja Scomber japonicas, Tfi Todarodes filippovae, Tmи Trachurus murphyi

from the cod-end in the Chilean hake trawl fishery. In order to overcome these biases caused by net-feeding, we strongly recommend analyzing stomach contents of D. gigas caught with jigs. However, this may also have limitations because the artisanal jigging fishery is very restricted spatially and temporally (Fig. 1). In these artisanal fleets we found jack mackerel, sardine, anchovy, Chilean hake, and Patagonian grenadier in stomach contents where these fishes are not the targeted species and so there appears to be a lower risk of bias. Field et al. (2007) reported Pacific hake as an important prey item for D. gigas in Californian waters; they also assessed the possibility of net feeding bias. Chong et al. (2005) and Fernández and Vásquez (1995) found that D. gigas caught with jigs fed on Chilean hake, jack mackerel and anchovy, but in smaller proportions. It is possible therefore that our results overestimate the occurrence of jack mackerel, sardine, Chilean hake and Patagonian grenadier in the diet of D. gigas. However, this bias in the diet could be dependent on the voracious behavior of large squid species, because the cuttlefish Sepia officinalis caught with three different types of fishing gear did not show significant differences in the diet (Pinczon du Sel and Daguzan 1997).

Excluding the target species from the analysis, the diet of jumbo squid exhibits geographic changes associated with depth of capture. In the oceanic zone (Fig. 1a), 
D. gigas mostly fed on pelagic fishes ( $S$. japonicus), myctophids, and squids, while in the neritic zone (Fig. 1c) it fed on pelagic fishes ( $S$. bentincki, E. ringens, $N$. crockeri and T. murphyi), demersal fishes (M. gayi, and M. magellanicus), euphausiids and benthic prey. The occurrences of this benthic prey, the sand crab E. analoga and snails $N$. gayi, suggests that the jumbo squid can feed near the coast on the bottom. Euphausiids were important in number, in artisanal purse-seine fleet catches, as in six stomachs we found between 1,000 and 3,000 individuals. D. gigas from the continental shelf zone (Fig. 1b) fed on a wide spectrum of myctophids, demersal fishes and cephalopods.

Cannibalism was also important in the diet of $D$. gigas during the present study. Markaida and Sosa-Nishizaki (2003) discuss how the artificial nature of this interaction is influenced during fishing operations. Off southern-central Chile we found that the cannibalism of $D$. gigas could be a result of stress behavior during capture rather than a consequence of natural feeding habits. We found a greater frequency of bite-sized pieces of other large squids, rather than smaller jumbo squid, in the stomach contents, and a similar observation was made by Field et al. (2007).

The impact of squid population on commercial fish stocks clearly implicates them as a factor influencing natural mortality and recruitment success (Rodhouse and Nigmatullin 1996). A classic example of this type of impact was reported by Ehrhardt (1991) who estimated that D. gigas consumed $60 \mathrm{kt}$ of sardines (S. sagax caerulea) during sardine migration into the Gulf of California in 1980, and based on these results suggested that a subsequent decline in sardine landings in 1981 was probably attributable to this increased predation pressure. In that paper, Ehrhardt (1991) analyzed stomach contents of D. gigas with samples obtained from purse-seine fishery targeting sardines, and the predation impact was overestimated by the bias in the sampling procedure. For this reason, the hypothesis concerning the decrease of M. gayi biomass off central Chile due to predation by D. gigas must be considered with caution. Similarly, we think that the coincident declines in the abundance of Pacific hake (Merluccius productus), the most important commercial groundfish species off western North America (Zeidberg and Robison 2007), and also of the stocks of Chilean hake, are not a response to jumbo squid predation but rather an interaction between climate change, predation and overfishing. To study such interactions further, we need detailed knowledge about the interaction between climate and ecological systems (Stenseth et al. 2002). In particular, we propose a quantitative comparison between the composition of the fisheries catch and of squid stomachs. We strongly recommend analyzing the stomach contents of squids caught with jigs at the same time and place as the trawl and purse-seine operations to avoid biases. Moreover, new tools that are being used as trophic indicators and tracers in food chain pathways include stable isotope, heavy metal and fatty acid signature analysis (Jackson et al. 2007). These tools and stomach contents from jigs may help to correctly study the diet of squids and achieve a better estimate of their impact on prey populations.

Acknowledgments We thank the Undersecretary of Fisheries (Subsecretaría de Pesca) of Chile for authorizing this research to estimate the population parameters of D. gigas. Other results were obtained from project FIP 2005-38 entitled "Impact of jumbo squid on Chilean trawl fisheries" (in Spanish; see http://www.fip.cl/ proyectos/FIP2005-38). We also thank Dr. Chingis M. Nigmatullin (Russia) and Dr. Unai Markaida (Mexico) for suggestions and comments on an early version of this manuscript. HA acknowledges Project INCOFISH (http://www.incofish.org) where results were discussed with colleagues participating in Work Package 4-Ecological Modelling. CM Ibáñez was supported by a CONICYT-Chile Doctoral Fellowship.

\section{References}

Amaratunga $\mathrm{T}$ (1983) The role of cephalopods in the marine ecosystem. In: Caddy JF (ed) Advances in Assessment of World Cephalopods Resources. FAO Fish Tech Papers 231:379-415

Breiby A, Jobling M (1985) Predatory role of the flying squid (Todarodes sagittatus) in north Norwegian waters. NAFO Sci Counc Stud 9:125-132

Castillo K, Ibáñez CM, Chong J, González C (2007) Dieta del pez espada Xiphias gladius Linnaeus, 1758 en distintas zonas de pesca frente a Chile central durante el otoño de. Rev Biol Mar Ocean 42(2):149-156

Chong J, Oyarzún C, Galleguillos R, Tarifeño E, Sepúlveda R, Ibáñez C (2005) Parámetros biológico-pesqueros de la jibia Dosidicus gigas (Orbigny, 1835) (Cephalopoda: Ommastrephidae) frente a la costa de Chile central $\left(29^{\circ} \mathrm{S}-40^{\circ} \mathrm{S}\right)$ durante $1993-1994$. Gayana 69(2):319-328

Clarke R, Paliza O (2000) The Humboldt Current squid Dosidicus gigas (Orbigny, 1835). Rev Biol Mar Ocean 35:1-39

Cubillos L, Ibáñez CM, González C, Sepúlveda A (2004) Pesca de jibia (Dosidicus gigas) con red de cerco entre la $\mathrm{V}$ y X Regiones, año 2003 (Project research). Inst Invest Pesq VIII Región, Talcahuano (Chile), pp 48

Ehrhardt NM (1991) Potential impact of a seasonal migratory jumbo squid (Dosidicus gigas) stock on a Gulf of California sardine (Sardinops sagax caerulea) population. Bull Mar Sci 49(1-2):325-332

Falabella F, Meléndez R, Vargas ML (1995) Claves osteológicas para peces de Chile central. un enfoque arqueológico, Editorial Artegrama, Santiago

Fernández F, Vásquez JA (1995) La jibia gigante Dosidicus gigas (Orbigny, 1835) en Chile: análisis de una pesquería efímera. Estud Oceanol 14:17-21

Field JC, Baltz K, Phillips AJ, Walker WA (2007) Range expansion and trophic interactions of the jumbo squid, Dosidicus gigas, in the California Current. Calif Coop Ocean Fish Invest Rep 48:131-146

Jackson GD, Bustamante P, Cherel Y, Fulton EA, Grist EPM, Jackson CH, Nichols PD, Pethybridge H, Phillips K, Ward RD, Xavier JC (2007) Applying new tools to cephalopod trophic dynamics and ecology: perspectives from the Southern Ocean Cephalopod Workshop, February 2-3, 2006. Rev Fish Biol Fish 17:79-99 
Jaksic FM, Marone L (2007) Depredación. In: Jaksic FM, Marone L (eds) Ecología de Comunidades $2^{\mathrm{a}}$ Edición. Ediciones Universidad Católica de Chile, Santiago, pp 69-90

Jobling M, Breiby A (1986) The use and abuse of fish otoliths in studies of feeding habits of marine piscivores. Sarsia 71:265-274

Jongman RHG, Ter Braaka CJF, Van Tongeren OFR (1995) Data analysis in communities and landscape ecology. Cambridge University Press, New York

Hyslop E (1980) Stomach content analysis - a review of methods and their application. J Fish Biol 17:411-429

Ibáñez CM, Cubillos LA (2007) Seasonal variation in the length structure and reproductive condition of the jumbo squid Dosidicus gigas (d'Orbigny, 1835) off central-south Chile. Sci Mar 71(1):123-128

Ibáñez CM, González C, Cubillos L (2004) Dieta del pez espada Xiphias gladius Linnaeus, 1758, en aguas oceánicas de Chile central en invierno de 2003. Invest Mar 32(2):113-120

Markaida U (2006) Food and feeding of jumbo squid Dosidicus gigas in the Gulf of California and adjacent waters after the 1997-1998 El Niño event. Fish Res 79(1-2):16-27

Markaida U, Sosa-Nishizaki O (1998) Food and feeding habits of swordfish, Xiphias gladius L., off western Baja California. In: Barrett I, Sosa-Nishizaki O, Bartoo N (eds) Biology and fisheries of Swordfish, Xiphias gladius. NOAA Technical Report 142:245-259

Markaida U, Sosa-Nishizaki O (2003) Food and feeding habits of jumbo squid Dosidicus gigas (Cephalopoda: Ommastrephidae) from the Gulf of California, México. J Mar Biol Assoc UK 83:116

Muñoz G, Valdebenito V, George-Nascimento M (2002) La dieta y la fauna de parásitos metazoos del torito Bovichthys chilensis Regan 1914 (Pisces: Bovichthydae) en la costa de Chile centrosur: variaciones geográficas y ontogenéticas. Rev Chil Hist Nat 75:661-671

Nesis KN (1987) Cephalopods of the world. T.F.H.Publications, New Jersey

Nigmatullin ChM (2005) Towards the correct methodology of cephalopod feeding study: review of some neglected problems. In: Third international symposium on Pacific squids. Lima, Peru, 28-30 November, 2005

Nigmatullin ChM, Nesis KN, Arkhipkin AI (2001) A review of the biology of the jumbo squid Dosidicus gigas (Cephalopoda: Ommastrephidae). Fish Res 54:9-19

Olson RJ, Román-Verdesoto MH, Macías-Pita GL (2006) Bycatch of jumbo squid Dosidicus gigas in the tuna purse-seine fishery of the eastern Pacific Ocean and predatory behaviour during capture. Fish Res 79:48-55
Pardo-Gandarillas MC, Garcías F, George-Nascimento M (2004) La dieta y la fauna de endoparásitos del pejesapo Gobiesox marmoratus Jenyns, 1842 (Pisces: Gobiesocidae) en el litoral central de Chile están conectadas pero no correlacionadas. Rev Chil Hist Nat 77:627-637

Pinczon du Sel G, Daguzan J (1997) A note on sex ratio, length and diet of a population of cuttlefish Sepia officinalis L. (Mollusca: Cephalopoda) sampled by three fishing methods. Fish Res 32:191-195

Pinkas L, Oliphant MS, Iverson IL (1971) Food habits of albacores, bluefin tuna and bonito in California water. Calif Fish Game 152:1-105

Retamal MA (1981) Catálogo ilustrado de los crustáceos decápodos de Chile. Gayana Zool 44:1-110

Rocha F, Vega MA (2003) Overview of cephalopod fisheries in Chilean waters. Fish Res 60:151-159

Rodhouse PG, Nigmatullin ChM (1996) Role as cosumers. Philos Trans R Soc Lond 351:1003-1022

Santos MB, Clarke MR, Pierce GJ (2001) Assessing the importance of cephalopods in the diet of marine mammals and other top predators: problems and solution. Fish Res 52:121-139

Stenseth NC, Mysterud A, Ottersen G, Hurrell JW, Chan K-S, Lima M (2002) Ecological effects of climate fluctuations. Science 297:1292-1296

Ulloa P, Fuentealba M, Ruiz V (2006) Hábitos alimentarios de Dosidicus gigas (D’Orbigny, 1835) (Cephalopoda: Teuthoidea) frente a la costa centro-sur de Chile. Rev Chil Hist Nat 79(4):475-479

Vaske-Júnior T, Rincón-Filho G (1998) Conteúdo estomacal dos tiburoes azul (Prionace glauca) e anequim (Isurus oxyrinchus) em águas oceânicas no sul do Brasil. Rev Bras Biol 58(3):445452

Wilhelm O (1930) Las mortandades de jibias (Ommastrephes gigas) en la Bahía de Talcahuano. Bol Soc Biol Concepc 3-4:23-28

Wilhelm O (1954) Algunas observaciones acerca de las mortandades de jibias (Dosidicus gigas D' Orb.), en el litoral de Concepción. Rev Biol Mar 4:196-201

Zar JH (1984) Biostatistical analysis. Prentice-Hall, New York

Zeidberg LD, Robison BH (2007) Invasive range expansion by the Humboldt squid, Dosidicus gigas, in the eastern North Pacific. PNAS 104:12948-12950

Zúñiga MJ, Cubillos LA, Ibáñez C (2008) A regular pattern of periodicity in the montly catch of jumbo squid (Dosidicus gigas) along the Chilean coast (2002-2005). Cienc Mar 34:91-99 